\title{
Complete atrioventricular block due to giant cell myocarditis
}

\author{
K. T. SinghaM* \\ M.B. B.S., M.R.C.P., F.R.A.C.P. \\ N. W. K. AzIzah $\dagger$ \\ M.B. B.S. \\ T. H. GoH $\dagger$ \\ M.B. B.S., M.R.C.P. \\ Departments of *Medicine and $\uparrow$ Pathology, University Hospital, Kuala Lumpur, Malaysia
}

\begin{abstract}
Summary
A rare instance of complete atrioventricular block due to giant cell myocarditis with histopathological correlation is documented. The haemodynamic changes and echocardiographic findings are described.
\end{abstract}

\section{Introduction}

Saltykow described giant cell myocarditis in 1905. Atrioventricular block is an unusual complication and only one such instance has been described in the English literature (Collyns, 1959). A second patient with a similar complication is now reported.

\section{Case report}

A 41-year-old man was found to have cardiomegaly on routine chest radiography in 1974. In January 1977 he developed epigastric discomfort and effort dyspnoea; in July 1977, electrocardiography showed complete atrioventricular block. In spite of pacing and anti-failure therapy the patient showed no improvement. Twenty days after admission he suddenly developed spontaneous bowel perforation and died.

At post-mortem the heart was enlarged and weighed $550 \mathrm{~g}$. All the chambers and the pulmonary outflow tract were dilated. The myocardium of both ventricles showed patchy areas of pale discoloration with thinning of the walls. There were multiple aseptic mural thrombi in both ventricles and the right atrial appendage. The coronary arteries were patent. Recent multiple pulmonary emboli with infarction of the middle and lower lobes of both lungs were present.

Histology of the heart showed patchy replacement of the myocardium by collagen-rich fibrous tissue infiltrated by lymphocytes and multinucleated giant cells. Some giant cells contained asteroid bodies while others showed cytoplasmic vacuolations. No granuloma formation was noted. Similar lesions involved the sino-atrial node (Fig. 1), atrioventricular node
(Fig. 2) and conducting fibres. Histological examin ation of the heart for acid fast bacilli, fungi, Enta moeba histolytica or other parasites were negative $\vec{\circ}$ Giant cells were not found in any other organ apart
from the heart.

The liver showed chronic passive venous congestion. Perforation of the caecum, and faeca peritonitis were secondary to intestinal amoebiasis. $\stackrel{\circ}{S}$

\section{Discussion}

Giant cell myocarditis is a condition where thereis histological evidence of myocarditis of unknowing cause with multinucleated giant cells with or without granuloma formation (Collyns, 1959; Dilling, 1956 Gubbay, 1961; Kean and Koekenga, 1952; McCreकू and Childers, 1964; Palmer and Michael, 1965; Rab® Choudhury and Choudhury, 1963). Various descrip $\overrightarrow{\vec{P}}$ tive terminology such as idiopathic giant celf myocarditis (Gubbay, 1961); giant cell granuloma-? tous myocarditis (O'Donnell and Mann, 1966)? granulomatous myocarditis (Long, 1961), Fiedler's myocarditis (Long, 1961 ; Parrish, 1965), have been. used as the aetiology and pathogenesis are not cleario (Pyunn et al., 1970).

Clinically, patients reported have presented witho sudden death, congestive heart failure or cardiac arrhythmias. Of specific interest in this case is the association of complete atrioventricular block and the histopathological changes in the atrioventricular node and the conducting system which revealed replacement by the abnormal tissue. Histopathological correlation of atrioventricular block in gian $\mathcal{O}^{-}$ cell myocarditis has been previously reported in onlyస్ట one other case (Collyns, 1959). Other electrocardio-0 graphic changes reported include non-specific Sto depression and $T$ wave changes (Gubbay, 1961 Palmer and Michael, 1965; Rab et al., 1963) right bundle branch block associated witho sinus tachycardia (Rab et al., 1963) and in another case report the cause of death was? 


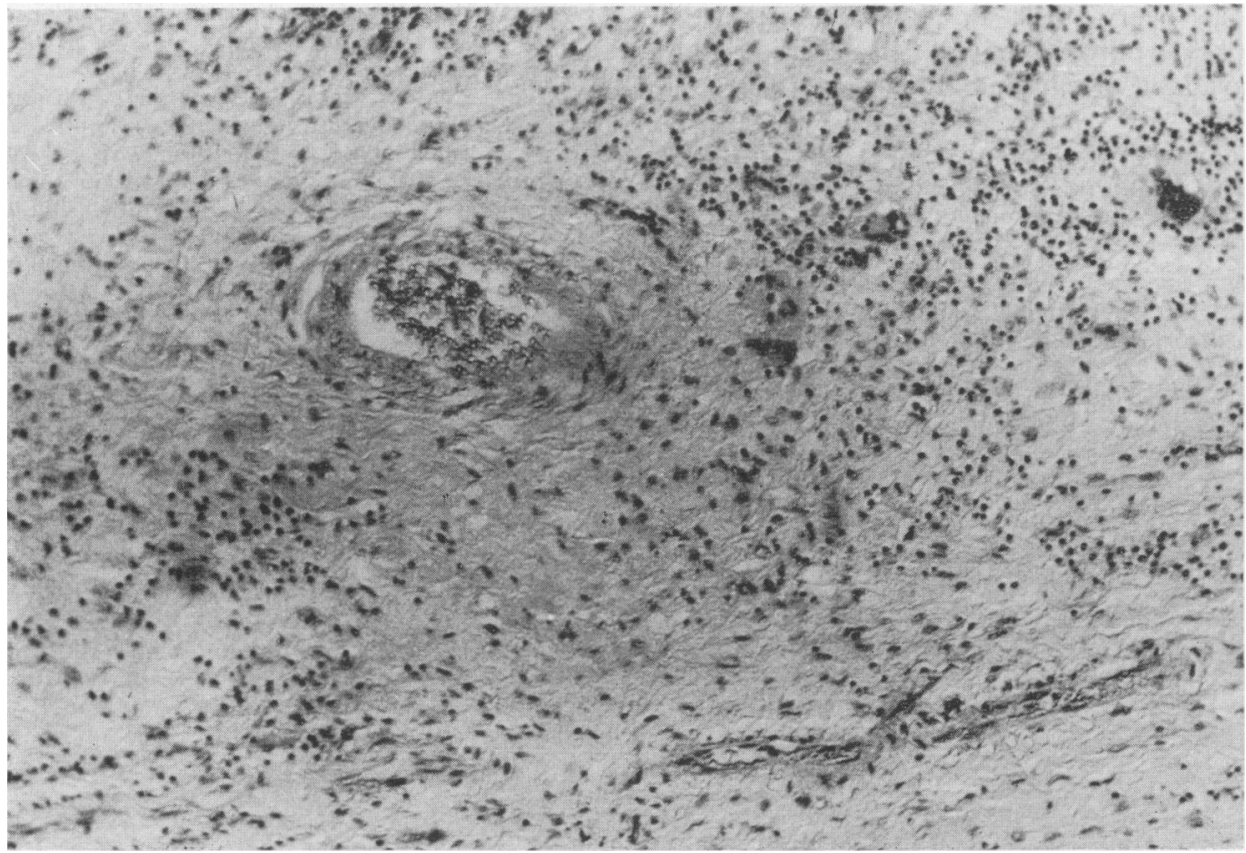

Fig. 1. Photomicrograph of the heart showing lesions involving the sino-atrial node.

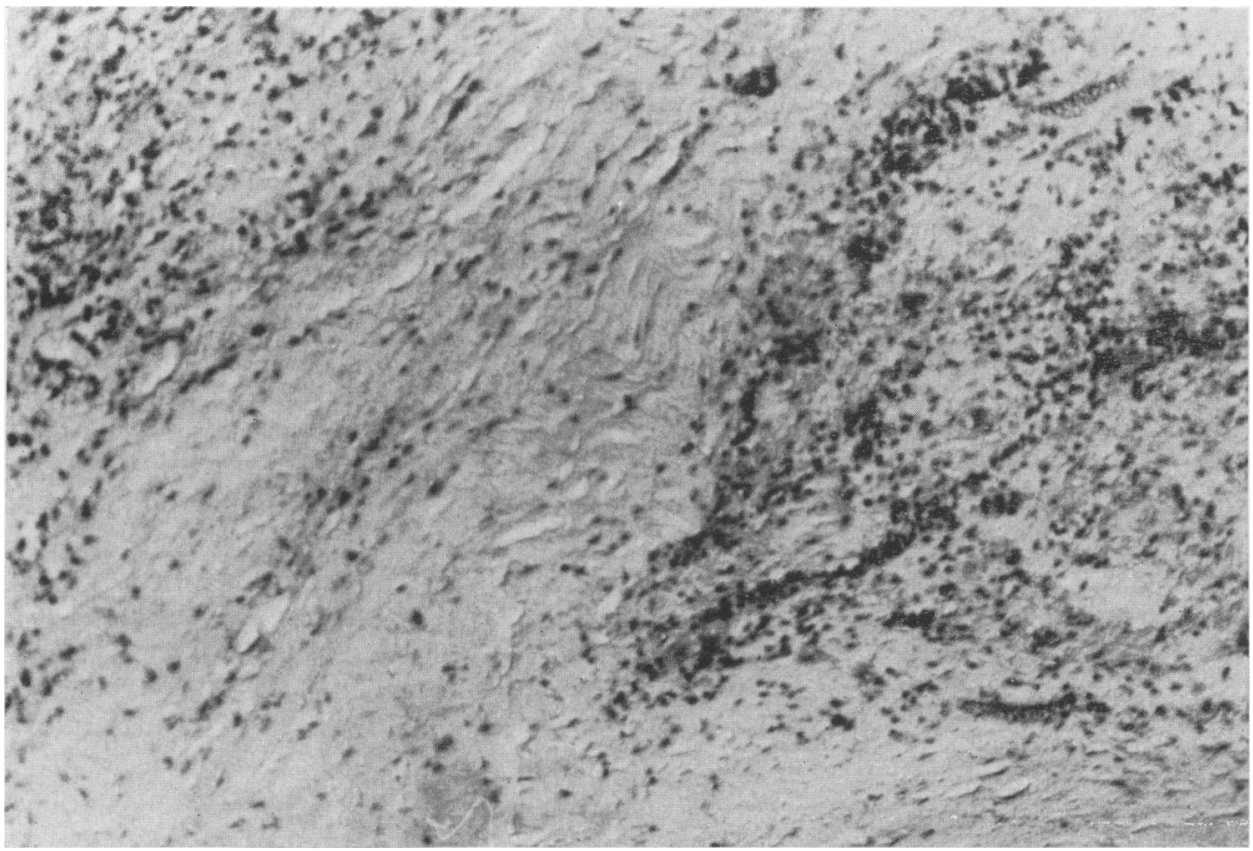

Fig. 2. Photomicrograph of the heart showing lesions involving the atrioventricular node. 
indicated as 'heart block, sino-auricular standstill, Adam-Stokes syndrome' but the electrocardiogram was not available (Kean and Koekenga, 1952).

\section{Acknowledgments}

We wish to thank Professor K. Prathap for advice, and Puan Rohani for typing the manuscript.

\section{References}

Collyns, J.A.H. (1959) Isolated granulomatous myocarditis. American Heart Journal, 58, 630.

Dilling, N.V. (1956) Giant cell myocarditis. Journal of Pathology and Bacteriology, 71, 295.

GubBaY, E.R. (1961) Idiopathic giant cell myocarditis. Canadian Medical Association Journal, 85, 349.

KeAN, B.H. \& KoeKengA, M.T. (1952) Giant cell myocarditis. American Journal of Pathology, 28, 1095.
LoNG, W.H. (1961) Granulomatous (Fiedler's) myocarditiş with extra-cardiac involvement. Journal of the Americar Medical Association, 177, 184.

McCrea, P.C. \& ChIlders, R.W. (1964) Two unusual cases of giant cell myocarditis associated with mitral stenosis and; with Wegener's syndrome. British Heart Journal, 26, 490.

O'Donnell, W.M. \& ManN, R.H. (1966) Asymptomatic giant cell granulomatous myocarditis. American Heart? Journal, 72, 686.

Palmer, H.P. \& Michael, I.E. (1965) Giant cell myocarditiss with multiple organ involvement. Archives of Interna⿸户 Medicine, 116, 444.

PARRISH, J.A. (1965) Fiedler's myocarditis. British Hearही Journal, 27, 458.

PyunN, K.S., Kim, Y.H., Katzenstein, R.E. \& Kikkawa, Y. (1970) Giant cell myocarditis: Light and electron microscopic study. Archives of Pathology, 90, 181

RaB, S.M., Choudhury, G.M. \& Choudhury, A.R. (1963) Giant cell myocarditis. Lancet, ii, 172. 